\title{
CARNAVAL BRASLLEIRO: EXPRESSÃO DA CULTURA POPULAR ADAPTANDO-SE AOS EFEITOS DAS TECNOLOGIAS CONTEMPORÂNEAS
}

\author{
Thiago Silva de Amorim Jesus
}

Universidade Federal de Pelotas

\section{RESUMO}

O presente texto apresenta algumas questões e exemplos que trazem à tona uma reflexão sobre estratégias que o carnaval brasileiro tem utilizado como modo de sobrevivência e adaptação da cultura popular aos efeitos das tecnologias contemporâneas, seja no uso destas no ambiente específico dos desfiles das escolas de samba do carnaval carioca, seja na configuração de novos modos de existir carnavalesco, como as escolas de samba de maquete.

Palavras-chave: Carnaval brasileiro. Escolas de samba. Tecnologia. Contemporaneidade. 


\section{Considerações iniciais}

$(1)$ carnaval que faz hoje o Brasil - e que acredito não deva ser entendido como "carnaval brasileiro", no singular, mas como "carnavais brasileiros", pela imensa diversidade estilística, estética e organizacional com a qual se apresenta em nosso país - não apresenta uma versão unânime na própria história de seu surgimento nem sobre sua denominação.

Sob uma perspectiva antropológica, DaMatta (1997) explica que o carnaval está junto daquelas instituições sociais que nos permitem sentir nossa própria continuidade como grupo. Segundo ele,

No carnaval, todo um conjunto de fatores sociais e históricos é combinado e recombinado para realizar o que percebemos como o carnaval antigo ou moderno, do interior e da capital, do Norte ou do Sul, dos ricos e dos pobres. Mas não se pode esquecer que isso ocorre desse modo porque todas essas situações são poderosamente dominadas pela ideia de que aqui temos um momento especial: fora do tempo e do espaço, marcado por ações invertidas; personagens, gestos e roupas características. (DAMATTA, 1997, p. 29).

Góes (2010) considera que o carnaval está atrelado de modo bastante contundente ao Brasil e ao seu povo e que seria possível afirmar que a festa se constitui em um de nossos mais marcantes traços identitários. $\mathrm{O}$ autor também atesta que o carnaval brasileiro revela múltiplas formas de expressão e reforça de modo decisivo a nossa diversidade cultural.

É extremamente difícil a tarefa de dimensionar com exata precisão as influências e vertentes que contribuíram e ainda contribuem para a composição e configuração estética do carnaval contemporâneo, uma vez que atualmente o processo veloz de comunicação, a internet e as inúmeras possibilidades de interação entre os povos do planeta são orientadores de uma cultura híbrida que contamina e é contaminada permanentemente mediante inúmeros atravessamentos e isso tem repercussão no carnaval tal qual em outros modos de expressão cultural da sociedade brasileira.

Um dos elementos mais afetados nessa relação entre pessoa e tecnologia - ser humano e técnica no contexto da cultura popular contemporânea - é o corpo, que é o principal meio de expressão das artes populares. A linguagem corporal é um elemento central da dança folclórica, música folclórica, artesanato popular, rituais folclóricos, teatro folclórico e muito mais.

De acordo com Sibilia (2015, p. 14),

$\mathrm{Na}$ atual "sociedade da informação", essa fusão entre o homem e a técnica se aprofundou e, por isso mesmo, está se tornando mais crucial e problemática. Certas áreas do saber constituem peças-chave dessa complexificação, como a 
teleinformática e as novas ciências da vida. Essas disciplinas, que, em princípio, parecem tão diferentes entre si, possuem uma base e uma ambição comuns: estão irmanadas no horizonte de digitalização universal que ilumina nossa era e marca seus compassos. Nesse contexto, precisamente, surge uma suspeita inusitada: o corpo humano, em sua antiga configuração biológica, estaria se tornando "obsoleto".

Vale ressaltar que, no tocante à configuração estética que compõe os diferentes momentos carnavalescos, presencia-se um sem-número de elementos extremamente peculiares que são orientadores das características pertinentes ao modo de ser e fazer carnaval em cada parte do Brasil. Assim, afirma-se que, embora possam haver recorrentes características associadas ao carnaval em todo o país, a festa assume ares próprios segundo o lugar no qual se realiza, adotando aspectos pertinentes à cultura local, que se incorporam ao carnaval nacional demarcando especificidades fundamentalmente associadas aos sujeitos que vivem naquele ambiente e contribuem para um processo de denominação e identificação do carnaval neste ou naquele lugar do país.

Podemos refletir sobre a peculiar posição ocupada pelos carnavais brasileiros, que se tornaram a festa secular mais popular do mundo, mas também um rico e entrelaçado mosaico de proezas artísticas, uma multiplicidade de eventos, organizações, fontes de renda e locais de trabalho, relações sociais, terreno fértil para experimentos tecnológicos e ensaios de mídia, berço de múltiplas culturas. Nesse sentido, é muito importante pensar a influência de diferentes aspectos da cibercultura na cultura popular, especialmente no carnaval brasileiro, por exemplo, no caso das mídias sociais, como YouTube, Vimeo, Instagram, Twitter e outras plataformas digitais, bem como a criação de novas possibilidades de carnaval, pensadas e produzidas especialmente para estes meios.

\section{A contemporaneidade no/do desfile carnavalesco}

Os recursos tecnológicos sempre foram uma marca bastante presente no âmbito dos desfiles do carnaval de rua, especialmente do Rio de Janeiro, que é palco protagonista do carnaval brasileiro. Contudo, particularmente na última década, diferentes inovações tecnológicas têm sido apresentadas de modo bastante contundente neste cenário, trazendo tecnologias de ponta à avenida e, com isso, interferindo diretamente na configuração estética do desfile carnavalesco de rua.

Tal tarefa nesse percurso impõe a necessidade de articulação de três conceitos bastante importantes para o cenário contemporâneo: Arte, Ciência e Tecnologia. Neste sentido, Domingues (2003, p. 11) traz:

As fronteiras difusas das pesquisas artísticas e científicas com tecnologias fazem aparecer no contexto contemporâneo um território entrecruzado de comple- 
xas camadas genealógicas: a sensibilidade da arte, a objetividade da ciência, a complexidade das tecnologias. A criatividade de artistas e cientistas configura hoje uma grande comunidade que, ao lado de sociedades científicas, instituições e centros de pesquisa contemporâneos, está engajada na busca de explorar características próprias de nosso cotidiano tecnologizado. Assim, pensar as relações entre arte e vida da perspectiva da ciência, do desenvolvimento tecnológico e da criação, com surpreendentes e envolventes aspectos sensíveis a partir da criatividade de artistas e cientistas do século XXI, é um dos desafios mais importantes deste início de milênio.

Neste sentido, entende-se que a presença massiva de tecnologias contemporâneas de ponta no carnaval acaba por interferir diretamente no processo criativo dos carnavalescos e comissões de carnaval com vistas à concepção e realização do desfile das escolas de samba. A tecnologia deixa de ser apenas um suporte para a realização e passa, de modo contundente, a incorporar-se na criação e ser, até por vezes, o dispositivo disparador do próprio processo, o que vem a contribuir com a consolidação da condição espetacular que o carnaval carioca assumiu nas últimas décadas.

Este entrelaçamento entre arte e ciência, arte e tecnologia, acabou por ressignificar a estética carnavalesca do carnaval carioca e, por consequência, de outros carnavais pelo Brasil afora, gerando opiniões e impressões diferentes sobre as transformações que foram ocorrendo. Luz $(2013$, p. 129) explica que

O carnaval das escolas de samba é costumeiramente chamado de Ópera de Rua no meio carnavalesco. Essa expressão é compartilhada por diversos profissionais das agremiações e por vários estudiosos do tema. A mistura do vocabulário e do conhecimento erudito-acadêmico com a espontaneidade e intuição dos sambistas dos morros cariocas começou a partir da entrada dos profissionais da Escola de Belas Artes do Rio de Janeiro no carnaval, na década de 1960. Desde então o carnaval tornou-se cada vez mais uma "ópera-balé ambulante", como conceituam Valença e Valença (1981), e acabou por deixar de ser mera brincadeira de rua para se tornar uma linguagem artística. Esse movimento em direção à constituição de uma linguagem artística encontrou ao longo da história do carnaval, e ainda encontra, muita resistência por parte dos turistas ligados à tradição e ao que chamam de "essência do carnaval". O desenvolvimento plástico que os desfiles ganharam com entrada de artistas formados na Escola de Belas Artes foi um divisor de águas na trajetória artística do carnaval das escolas de samba que, porém, não se permitiu estacionar aí.

Paulo Barros, um dos carnavalescos mais destacados da nova geração do Grupo Especial das Escolas de Samba do Rio de Janeiro, pode ser trazido como um dos exemplos mais bem-sucedidos neste processo de adaptação e uso de tecnologias 
contemporâneas no desfile carnavalesco de rua. Atualmente como carnavalesco na Escola de Samba Unidos do Viradouro (agremiação que retorna à elite do carnaval carioca em 2019), Barros tem apresentado em seus desfiles uma série de inovações tecnológicas que corroboram a assinatura conceitual e estética que é sua marca registrada.

Pode-se dizer que um dos momentos inaugurais e mais simbólicos proporcionados por Barros no Sambódromo da Sapucaí foi no vice-campeonato da Escola de Samba Unidos da Tijuca, em 2004, com o enredo Samba-Enredo 2004 - O Sonho da Criação e a Criação do Sonho: a Arte da Ciência No Tempo do Impossível. É neste desfile que Paulo Barros apresenta um novo modo de apresentação e visualidade para os carros alegóricos, a partir da perspectiva de "alegoria humana".

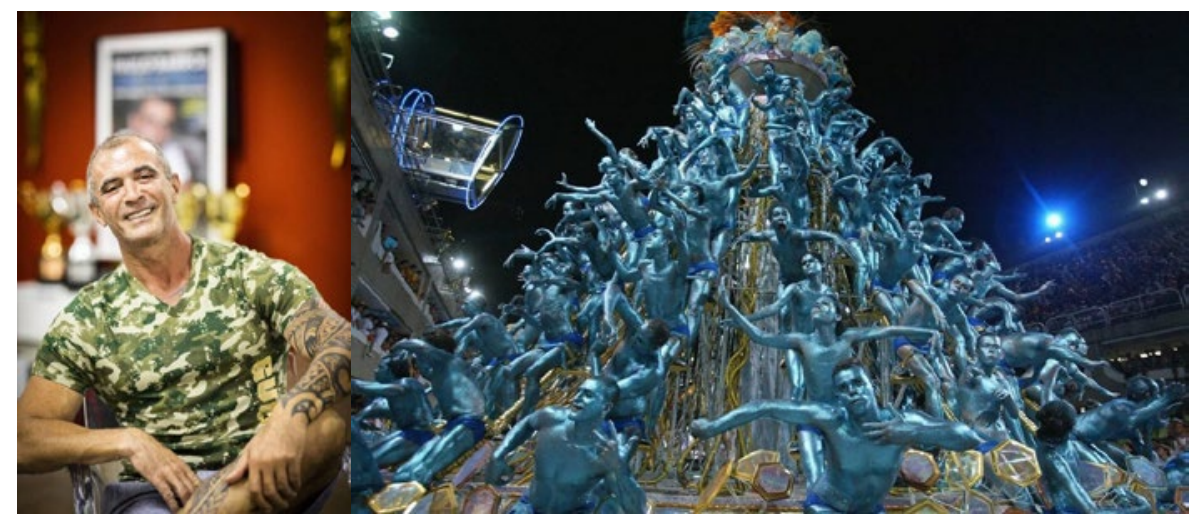

Figuras 1 e 2. Paulo Barros (esquerda) concebeu o Carro do DNA (direita) para a Unidos da Tijuca, em 2004. Fonte: Lopes (2018) e Teixeira (2004).

Luz (2013) menciona, ainda, o referido artista no âmbito do que a autora chama de "nova revolução" pela qual passa o carnaval na atualidade:

Neste século XXI houve nova revolução [no Carnaval do Rio de Janeiro], com desfiles cada vez mais teatralizados e conceitualmente elaborados, a partir, principalmente, do trabalho do carnavalesco Paulo Barros, que vem exercendo forte influência em muitas escolas. Com isso, novamente se reconduziu essa linguagem para novos caminhos expressivos e estéticos. (LUZ, 2013, p. 129).

De lá para cá, Barros protagonizou também outros momentos importantes no Carnaval do Grupo Especial do Rio de Janeiro, em que as novas tecnologias tiveram papel decisivo na assinatura estética dos desfiles. A seguir, ilustramos com dois exemplos estas inovações tecnológicas trazidas por ele para o desfile carnavalesco. 


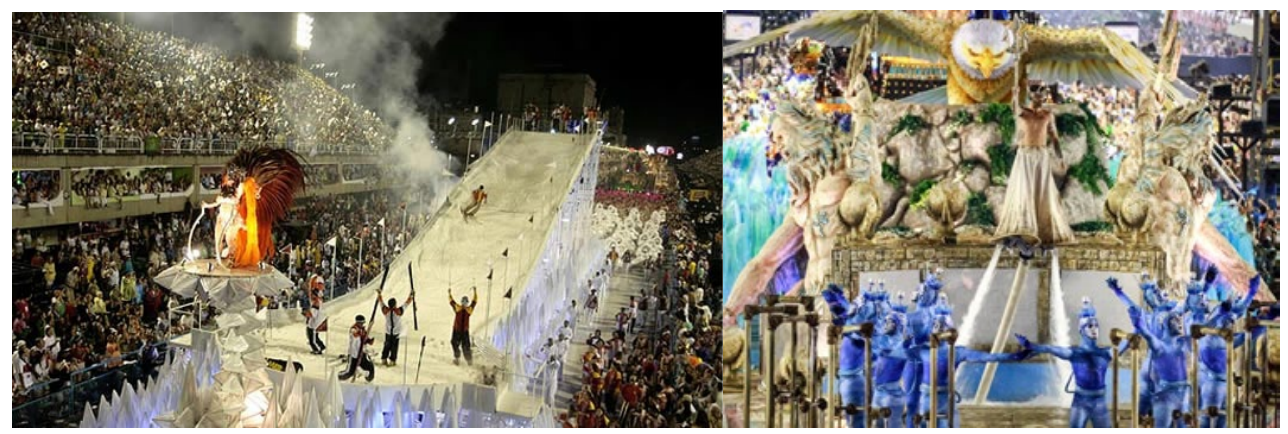

Figuras 3 e 4. Na imagem da esquerda, uma pista de esqui é montada em um carro alegórico no desfile da Unidos do Viradouro, em 2007; à direita, Poseidon, que flutuou com uma prancha (flyboard) e jatos de água na comissão de frente da Portela, em 2016. Fonte: CS Team (2018) e Gorosito (2016).

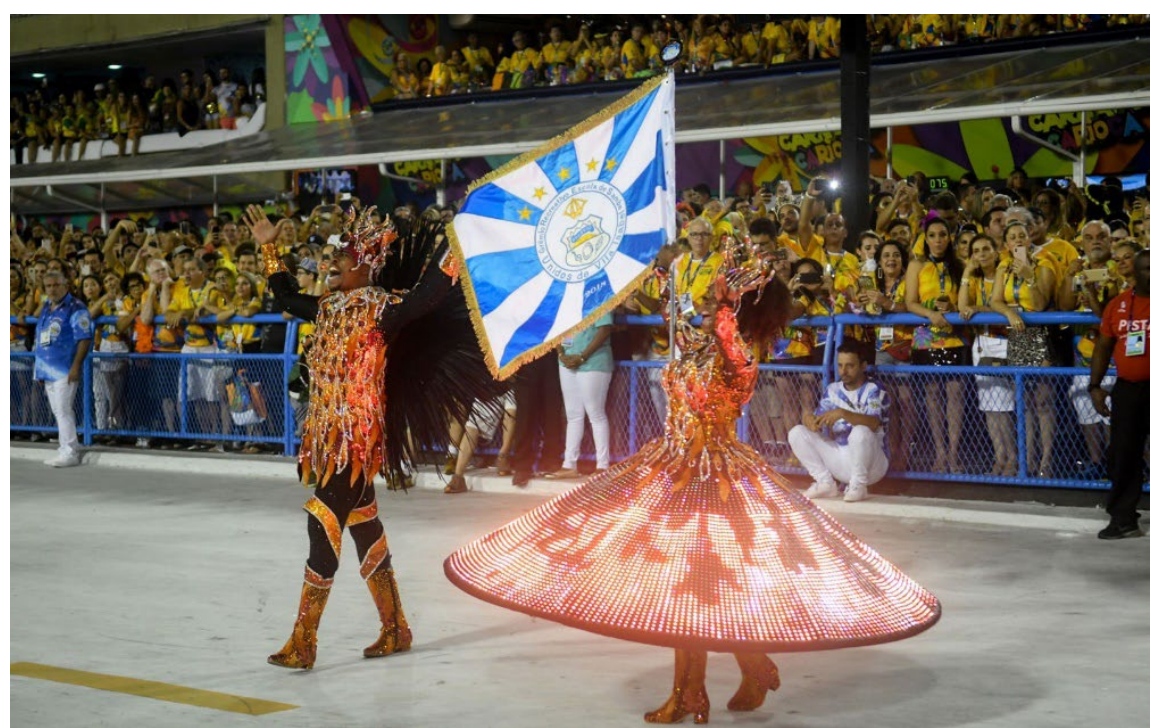

Figura 5. Saia da porta-bandeira apresenta efeito de fogo artificial com 20 mil lâmpadas de LED no desfile da Unidos de Vila Isabel, assinado por Paulo Barros, em 2018. Fonte: Durão (2018).

Além de Paulo Barros, outros carnavalescos e escolas de samba também têm aderido a diferentes tecnologias da contemporaneidade e utilizado tais recursos nos seus processos de criação e de realização dos desfiles de carnaval. A cada ano, é possível perceber uma presença progressiva e contundente da tecnologia como um elemento já constituinte e inerente à poética dos desfiles, que é projetada por cada escola de samba, conforme ilustramos a seguir. 


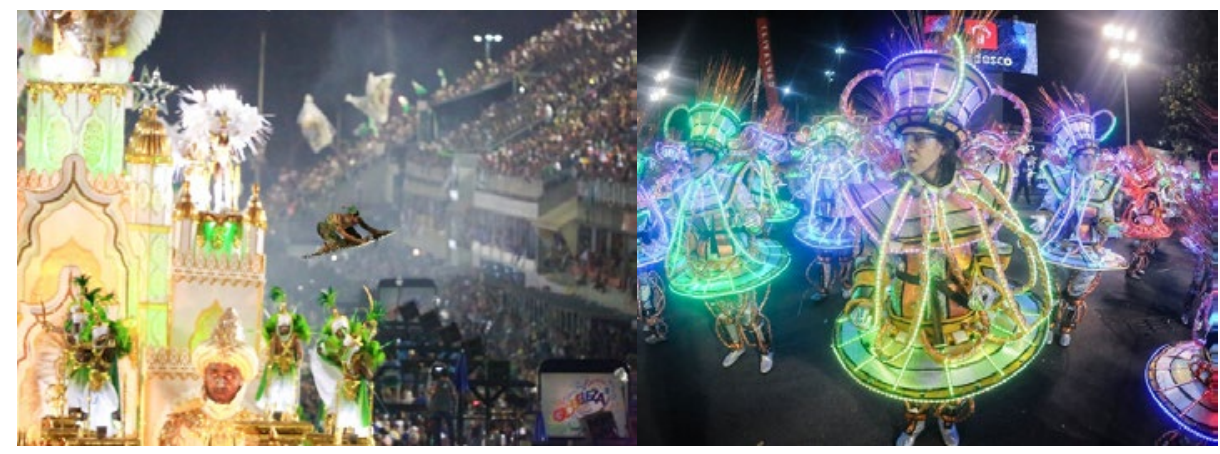

Figuras 6 e 7. Com o carnavalesco Alexandre Louzada, a escola de samba Mocidade Independente de Padre Miguel traz Aladdin voando pela avenida por meio de um aeromodelo, em 2017 (esquerda); na Unidos da Tijuca, em 2015, a comissão de carnavalescos composta por Mauro Quintaes, Annik Salmon, Marcus Paulo, Carlos CarvaIho e Hélcio Paim esbanjou tecnologia com alas de fantasias bastante iluminadas (direita). Fonte: Gorosito (2017) e 3M Inovação (2015).

Há que se considerar também que um fator importante neste processo de tecnologização high-tech das escolas de samba é o orçamento. Via de regra, o investimento em tecnologias avançadas e de ponta, ou mesmo o desenvolvimento de novas tecnologias específicas ou adaptadas ao contexto do carnaval, representa um custo alto para as agremiações carnavalescas, e não são todas elas que dispõem de dinheiro suficiente para efetivar investimentos desta natureza.

É importante ressaltar que estes exemplos aqui mencionados se referem à elite do carnaval brasileiro, que é o Carnaval das Escolas de Samba do Grupo Especial do Rio de Janeiro, e não representa a realidade de todos os cenários carnavalescos do país, tampouco do carnaval do próprio estado referido. Todavia, inclusive considerando o que representa este carnaval e sua influência para os mais diferentes contextos carnavalescos dos desfiles de rua do Brasil, é possível perceber que a presença de novas tecnologias que habitam o cotidiano da sociedade como um todo também afeta os mais distintos cenários carnavalescos, mesmo que em proporções diferentes e, logicamente, por meio de investimentos e orçamentos adequados a cada realidade.

Mas não é só o uso de equipamentos e materiais que faz a tecnologia estar presente nos desfiles carnavalescos das escolas de samba do Rio de Janeiro. O tema "tecnologia" também é uma constante nos enredos das agremiações do carnaval, cada vez mais sendo problematizado e estimulando a reflexão sobre a presença dos adventos tecnológicos em nossas vidas e seu impacto junto à natureza e ao meio ambiente.

Em 2018, a Unidos de Vila Isabel apresentou o enredo Corra que o futuro vem aí, um tema de extrema relevância que apontou para os diferentes aspectos da relação entre tecnologia e meio ambiente, em que o futuro ali mencionado nada mais é do que um modo de entender o próprio tempo presente, conforme destaca o site Ambiente Brasil (2018): 
O alerta da Vila Isabel será feito pela apresentação das trajetórias das descobertas e invenções tecnológicas pelo homem e os seus impactos no meio ambiente: o futuro da espécie humana depende da conservação ambiental. A história da tecnologia desenvolvida pelo ser humano é entoada em descobertas como os moinhos, as grandes navegações, os meios de comunicação e as ciências, de um modo geral. Como sabemos, os avanços tecnológicos que até então alcançamos fizeram com que conquistássemos muitas vitórias, a erradicação de várias doenças, a comunicabilidade remota, entre tantas outras maravilhas. Porém, tais maravilhas têm um custo enorme que quem está pagando é a Natureza. Por isso, devemos tomar as rédeas deste avanço científico para preservar nossas vidas. (AMBIENTE BRASIL, 2018).

Como trouxe a própria letra do samba-enredo desta escola: “Hoje pensar em ciência, é ter consciência do que está por vir... Então pra que desistir? Corra que o futuro vem aí". Assim, pode-se dizer que, pouco a pouco, a linguagem tecnológica vai se incorporando à linguagem folclórica e amalgamando a cultura contemporânea à cultura popular, num movimento quase integralmente harmônico.

\section{Tecnologias em rede: o carnaval das/nas mídias}

Pensar neste processo de adaptação da cultura popular aos múltiplos e diversos efeitos das tecnologias contemporâneas significa atentar para a presença cada vez maior e mais abrangente das mídias, redes sociais e dispositivos móveis no nosso cotidiano. $\mathrm{E}$ isso não é diferente em se tratando de cultura carnavalesca.

Está há muito no passado o tempo em que o único meio de assistir à transmissão do desfile das escolas de samba do carnaval carioca era pela televisão, ao vivo e sem repetição, exclusivamente no dia e horário estabelecidos pela emissora responsável no país por transmitir na televisão aberta.

Atualmente, existem diversos canais on-line (YouTube, Vimeo e outras plataformas) que transmitem os desfiles ao vivo, com direito ao antes, durante e depois de comentaristas, especialistas ou não em carnaval, transmissões estas que contam com diferentes investimentos, recursos e qualidades técnicas. Além disso, os recursos de vídeo ao vivo, stream, Facebook Live, Twitter ou Instagram Live também são outras estratégias de difusão e transmissão ao vivo, tanto quanto as web radios, onde qualquer pessoa pode gerar conteúdo e exibir os desfiles e qualquer outro momento do carnaval, ao vivo, de modo gratuito.

Ambas as possibilidades mencionadas, assim como inúmeras outras que este trabalho não daria conta de citar ou enumerar, apontam para novos paradigmas de difusão e comunicação das imagens e conteúdos produzidos pelo carnaval, onde o emissor nem possui mais a ilusão de controle das informações que são produzidas, porque não faz sentido algum. Tudo está aberto, desnudado, despido, público, irrestrito, democratizado e potente de infinitos atravessamentos e (re)produções de sen- 
tido afetadas pela condição da virtualidade, da simultaneidade e da interatividade.

Segundo Couchot, Tramus e Bret (2003, p. 32), vivemos em um momento em que

A interatividade atingiu uma etapa superior em complexidade e autonomia. Nesse sentido, ela segue a evolução da cibernética. Enquanto a "primeira cibernética" se perguntava mais sobre as noções de controle e de comunicação (no animal e na máquina) e de informação, a segunda cibernética se interroga preferencialmente sobre as noções de auto-organização, sobre estruturas emergentes, redes, questões de adaptação e de evolução. De uma maneira análoga, enquanto a primeira interatividade se interessava pelas interações entre o computador e o homem, num modelo estímulo-resposta ou ação-reação, a segunda se interessa mais pela ação enquanto guiada pela percepção, pela corporeidade e pelos processos sensório-motores, pela autonomia (ou pela "autopoièse"). [...] O diálogo do homem e da máquina torna-se mais afinado.

Estes cenários fazem com que também as escolas de samba e os demais agentes vinculados ao ambiente de gestão e difusão do carnaval se interessem e se atentem para o ambiente virtual de modo dedicado, criando canais em diversas plataformas e redes sociais para interagir com seus públicos, produzir novos conteúdos, entre outras múltiplas possibilidades de colaboração e coparticipação.

É praticamente impensável para a atualidade conceber uma escola de samba, especialmente as de maior representatividade, que não tenha um bom planejamento e contundente atuação nas redes sociais e plataformas multimídia. Tal condição passa a ser um pré-requisito, inclusive, para ter um bom retorno financeiro e um aceitável espectro de investimentos de empresas que buscam nessa visibilidade a contrapartida de retorno para o dinheiro investido no carnaval.

As próprias entidades carnavalescas passaram a transmitir os eventos e momentos importantes das suas rotinas durante o ano, tais como coroação de rainhas, festas temáticas, apresentação de enredo e concursos de samba-enredo, entre outros. Esta estratégia "abre", de certa forma, o interior da escola de samba para as comunidades (real e virtual) e permite um conhecimento e familiarização com os cotidianos do fazer carnavalesco, bem como aproxima as pessoas que vivem longe e/ou que não têm condições de estar presentes nestes momentos do dia a dia da agremiação.

A popularidade nas redes e também uma atuação ampla em termos de comunicação e divulgação durante o ano são fatores contribuintes, ainda, para o aumento do número de simpatizantes das escolas e mesmo dos torcedores que comparecem presencialmente nos dias de desfile no Sambódromo, no período carnavalesco, que são parte importante para a energia e desempenho destas entidades.

A web também se configura num espaço de múltiplas possibilidades de existência do carnaval, para além dos fazeres tradicionais. As plataformas multimídia tornam-se passarelas, quadras de samba, sambódromos... enfim, espaços de criação 
de novas poéticas carnavalescas, que, mesmo inspiradas nas formas tradicionais do fazer folclórico do carnaval, propõem novos paradigmas de existência estética para o carnaval da contemporaneidade, adaptando-se aos novos tempos.

Exemplo deste novo conceito de carnaval criado no e a partir do contexto tecnológico contemporâneo, atravessado por ele e por ele absolutamente influenciado, são as Escolas de Samba de Maquete.

O Carnaval de Maquete é um movimento carnavalesco relativamente recente que ganhou bastante força e projeção na última década e vem conquistando novos adeptos a cada ano, por meio de desfiles de escolas de samba criados e realizados especificamente para o ambiente virtual. Um dos coletivos importantes de organização e gestão deste formato é a UESM (União das Escolas de Samba de Maquete), fundada em 2013.

A UESM é uma entidade organizada que tem website ${ }^{1}$ e regulamento próprios, e que coordena e gestiona os critérios, processo avaliativo e formativo do seu carnaval e, especialmente, os desfiles das Escolas de Samba de Maquete, tanto do Grupo Especial, quanto dos Grupos de Acesso.

De acordo com o Regulamento da entidade:

[...] A UESM existe para possibilitar espaço de criação e divulgação do trabaIho de artistas (profissionais ou amadores) do carnaval, sendo estes atuantes no carnaval real ou não, tais como carnavalescos, diretores de carnaval, intérpretes, compositores, presidentes, coreógrafos e demais artistas de carnaval, com o intuito de que, por meio de seus desfiles, possam ao mesmo tempo brincar de fazer carnaval e mostrar sua produção ao público. Por esse motivo, essa produção precisa ser original, única e autoral. Todos são incentivados a criarem seus próprios desfiles ou fazer releituras ou reedições de enredos e desfiles, porém, dando a eles um formato inédito. [...] Entende-se por "releitura" ou "reedição" de um enredo a criação de uma narrativa nova que tenha como base um enredo já executado, sem, no entanto, replicar o espetáculo em suas formas e organização técnica (planta baixa de desfile, roteiro, sinopses etc.). [...] Apesar de se tratar de um desfile de carnaval em maquete, não são aceitas as miniaturizações de desfiles reais, compreendendo-se como miniaturização a produção de fantasias, adereços ou alegorias, ou quaisquer outros elementos de desfile que caracterizem a reprodução em escala menor de elementos já utilizados em desfiles outros. [...] São vetadas as repetições de formas, mesmo que em escala menor, de elementos apresentados de desfiles originais (reais) ou de outras ligas virtuais ou de maquete nos quais a escola se inspirou para fazer a releitura de carnaval.

1 Website da UESM disponível em: http://www.uesm.com.br. 
Ao assistir a um vídeo do desfile de Escolas de Samba de Maquete, é possível perceber a riqueza de detalhes e o respeito aos conceitos criativos do carnaval que é apresentado/realizado na avenida "real", no Sambódromo. Mesmo utilizando-se de uma nova mídia, um novo recurso de difusão e alguns aspectos de adaptação em relação ao formato tradicional, não há como negar que se trata de escolas de samba que foram concebidas, idealizadas e projetadas para um desfile real-virtual.

As normatizações estabelecidas como parâmetros pela União das Escolas de Samba de Maquete deixam claro o propósito, onde as agremiações participantes devem compor uma "apresentação construída a partir da utilização de maquetes e bonecos em miniatura que simula, adapta e recria o modelo de desfile das escolas de samba do carnaval real" (UESM, 2018).

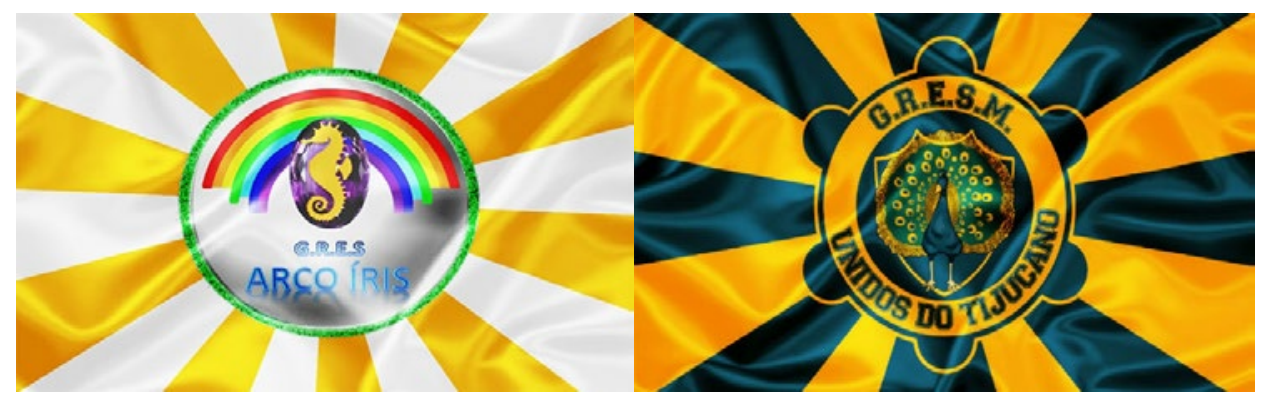

Figuras 8 e 9. Bandeiras virtuais das Escolas de Samba de Maquete que foram campeãs em 2018; à esquerda, G.R.E.S. Arco Íris, que conquistou o Grupo de Acesso; e, à direita, G.R.E.S.M. Unidos do Tijucano, campeã do Grupo Especial, ambas pela UESM. Fonte: UESM.

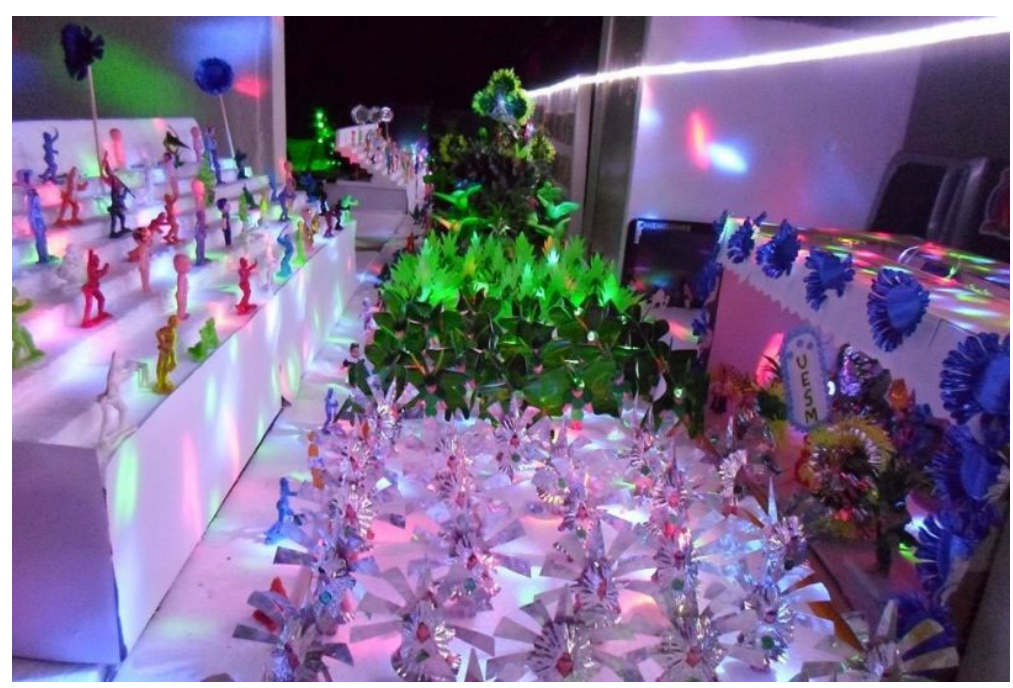

Figura 10. Em 2017, a Escola de Samba de Maquete Império de Ouro Branco foi campeã do Grupo Especial com o enredo Das areias do deserto uma cultura milenar. Egito. Fonte: Tesi (2017).

Como curiosidades do trabalho de carnaval das Escolas de Samba de Maquete, é possível destacar que um desfile de maquetes pode custar de $\mathrm{R} \$ 50$ até $\mathrm{R} \$ 1$ mil, 
sem enredo patrocinado, e os quesitos de avaliação são os seguintes: Comissão de Frente, Conjunto, Fantasias, Alegorias e Adereços, Enredo, Mestre-Sala e Porta-Bandeira e Evolução, com notas que vão de 8 a 10.

A respeito das técnicas utilizadas para a realização do desfile virtual, o site especializado em Carnaval "SETOR 1" explica:

No caso de comissão e casal, as escolas fazem coreografias com os bonecos, animadas com a técnica stop-motion. Para mestre-sala e porta-bandeira, repete-se apresentações de casais famosos de escolas reais. [...] À frente da bateria, há também uma rainha, como nos desfiles reais. E elas são versões em boneca de componentes de verdade [...]. Já em Evolução, as semelhanças com o julgamento das escolas reais são semelhantes: verifica-se que as alas não estão muito espaçadas, por exemplo. Mas os jurados devem ver se há desequilíbrio no tempo usado para exibir alas e carros. Se uma escola mostra o abre-alas por muito tempo e passa rapidamente pelas baianas, o julgador pode "canetar". O trabalho do editor, nesse caso, lembra o de um diretor de harmonia. (TESI, 2017).

Acredita-se, cada vez mais, que o carnaval brasileiro está se adaptando ao contexto veloz e diversificado da contemporaneidade, utilizando-se de recursos tecnológicos para atuar diretamente no seu contexto criativo de produção dos desfiles, bem como produzindo novos modos do fazer folclórico carnavalesco, como no caso das Escolas de Samba de Maquete. Também há que se destacar a crescente inserção nas temáticas carnavalescas do debate sobre a presença da tecnologia em nossas vidas, problematizando e chamando a atenção para o que estamos vivendo e também sobre o que está por vir, desde o futuro mais breve até o mais longínquo.

Tomando como referência este tipo de arte popular em formato eletrônico, que é o Carnaval de Maquete, pode-se dizer que já é uma realidade que se configura como possibilidade de atualização e adaptação da cultura folclórica ao contexto contemporâneo da cibercultura. Nas palavras de Mariátegui (2003),

A arte eletrônica representa uma oportunidade para artistas e cientistas desenvolverem novos modos de interatividade, encontrando novas linguagens em formas interativas. A interatividade conseguirá chegar a seu pleno esplendor quando o computador puder cultivar relações com cada espectador independentemente, e a parte "inter" da interatividade reconhecer a participação do espectador. (MARIÁTEGUI, 2003, p. 162).

A presença das tecnologias em nossa sociedade é um caminho sem volta. Mesmo que diferentes artefatos tecnológicos sejam utilizados pelo homem desde os tempos mais primitivos (como a roda, por exemplo), é na contemporaneidade das revoluções científicas e tecnológicas que as mudanças mais bruscas e assustadoras têm se desdobrado e interferido de modo decisivo em tudo o que tem a ver com nosso cotidiano. 
Considero que a cultura folclórica e a cultura tecnológica não são autoexcludentes e que conseguiremos encontrar (assim como já estamos encontrando) alternativas de cossobrevivência mútua, em que o novo se inspira no tradicional e o tradicional faz uso do novo para produzir uma nova geração híbrida, capaz de superar os desafios que ainda estão por vir.

\section{Considerações finais}

O carnaval é uma expressão da cultura popular no Brasil que foi criada e transformada ao longo de muitas décadas, sempre se vinculando ao contexto e às respectivas tecnologias, expressando assim sua forte relação com a cronologia, a época e o calendário. É possível pensar que essa característica é um tipo de estratégia para sobreviver e se adaptar constantemente.

Através do carnaval, o povo brasileiro inverte, reverte e subverte a ordem cotidiana temporal e controlada ao longo do ano, reservando-se o direito de criar um novo modo de vida no período carnavalesco, que hoje só é possível de ser pensado/ entendido como absolutamente influenciado pelo contexto tecnológico da contemporaneidade.

A tecnologia está presente como modo de atualização da manifestação folclórica carnavalesca, como imersão real-virtual no cenário contemporâneo da cibercultura e também na atualização e (re)configuração estética e conceitual da manifestação, com vistas à manutenção do caráter atrativo de espetáculo que as escolas de samba assumiram. Esta dualidade entre a manutenção da tradição e a assunção de novos modos de existir das manifestações na atualidade, todavia, gera uma reflexão interminável e sem nenhum vencedor.

Luz (2013), a respeito do embate entre tradicional e contemporâneo, lembra:

Desde a criação das escolas de samba, no Rio de Janeiro, no final da década de 1930, proveniente dos ranchos e cordões, houve quem desse um passo adiante, reinventando uma convenção, como também houve quem bradasse, injuriado, contra esse passo, defendendo a convenção. No ano seguinte, no entanto, muitos dariam o mesmo passo, tornando a invenção do ano anterior uma nova convenção. E assim o carnaval foi-se dialogicamente autoconstruindo, permitindo-se ser uma obra aberta que tem permissão para reinventar-se, retornando a seu passado para buscar novas referências para o futuro. (LUZ, 2013, p. 130).

As transformações das manifestações folclóricas são inevitáveis ao longo dos tempos. Os lugares não são mais os mesmos, os climas e as temperaturas não são mais os mesmos, os tecidos, produtos, materiais, equipamentos, tecnologias, conceitos e pessoas também não são os mesmos. A cultura é dinâmica e, por conta disso, não é mais a mesma, fazendo com que o folclore também não o seja. 
Manter uma visão essencialista e intocavelmente romântica sobre estes assuntos é quase uma atitude de incongruência com o que presenciamos cotidianamente. Devemos, sim, respeitar as tradições folclóricas e tudo o que elas representam como legado, todavia não podemos fechar os olhos para os novos modos de ser, fazer e existir que estamos vivendo, em que o real e o virtual têm fronteiras cada vez mais tênues e indefiníveis. Mariátegui (2003), neste sentido, alerta:

\begin{abstract}
O sucesso da ciência hoje não se baseia somente nesses resultados tecnológicos, mas também em uma combinação cuidadosa e equilibrada de inventividade e controle. É fundamental que a relação entre as novas mídias e as mídias antigas se desenvolva como uma coevolução, mas sob uma nova perspectiva em que natureza e máquina se unem formando uma coisa só. De alguma maneira, isso significará que não se encontrará nenhuma diferença importante entre as experiências reais e virtuais. (MARIÁTEGUI, 2003, p. 163).
\end{abstract}

Temos que estar preparados ou, mais do que isso, abertos às novas possibilidades de existência do carnaval (e de toda a sorte de manifestações das culturas popular e folclórica) na contemporaneidade. Novos tempos pedem novas atitudes. Contudo, uma certeza defendemos aqui: independentemente da forma e do modo, o carnaval não deixará de existir por muito tempo, seja por meio de uma escola de samba "real", seja por uma escola de samba de maquete, ou mesmo algum outro modo do fazer carnavalesco que se apresentar e encontrar estratégias de sobrevivência neste cenário tecnológico.

\title{
Referências
}

3M INOVAÇÃO. O carnaval na era da inovação. 2015. Disponível em: https:// www.3minovacao.com.br/blog/o-carnaval-na-era-da-inovacao. Acesso em: 17 set. 2018.

BRISO, Caio Barretto. O novo mago da Sapucaí. Isto É, 19 fev. 2010. Disponível em: https://istoe.com.br/51822_O+NOVO+MAGO+DA+SAPUCAl/. Acesso em: 17 set. 2018.

"CORRA que o futuro vem aí": tecnologia e meio ambiente no carnaval 2018. Ambiente Brasil, 9 fev. 2018. Disponível em: https://noticias.ambientebrasil.com. br/clipping/2018/02/09/141763-"corra-que-o-futuro-vem-ai"-tecnologia-e-meioambiente-no-carnaval-2018.html. Acesso em: 22 set. 2018.

COUCHOT, Edmond;TRAMUS, Marie-Hélène; BRET, Michel. A segunda interatividade. Em direção a novas práticas artísticas. Trad. Gilse Boscato Muratore e Diana Domingues. In: DOMINGUES, Diana (org.). Arte e vida no século XXI: tecnologia, ciência e criatividade. São Paulo: Ed. Unesp, 2003. 
CS TEAM. Sambódromo Viradouro, Rio de Janeiro. CS Team, Rio de Janeiro, fev. 2008. 1 fotografia. Disponível em: http://www.csteam.com.br/noticias/fotos/not030/ foto01.jpg.

DAMATTA, Roberto. Carnavais, malandros e heróis: para uma sociologia do dilema brasileiro. 6. ed. Rio de Janeiro: Rocco, 1997.

DURÃO, Alexandre. O primeiro casal de mestre-sala e porta-bandeira da Vila Isabel simboliza a descoberta do fogo. G1, Rio de Janeiro, 12 fev. 2018. 1 fotografia. Disponível em: https://s2.glbimg.com/ NniZELP4aPbygIYMtJcpusX4noc=/0x0:1700×1065/1008x0/smart/filters:strip_ icc()/i.s3.glbimg.com/v1/AUTH_59edd422c0c84a879bd37670ae4f538a/internal_ photos/bs/2018/S/v/HtHI7iSMCGdOvJG8czaA/d-users-fcarvalh-downloads-vilaisabel-dsc-7602-alexandre-durao-g1.jpg.

GÓES, Fred. A imagem do carnaval brasileiro: do entrudo aos nossos dias. Revista Textos do Brasil, Brasília: Ministério das Relações Exteriores, n. 15 (Festas Populares), 2010.

GOROSITO, Rodrigo. Abre-alas da Portela teve flyboard. G1, Rio de Janeiro, 9 fev. 2016. 1 fotografia. Disponível em: http://s2.glbimg.com/mtRUW8TXIWWatmmdNSr_ yFdqKaU=/620x465/s.glbimg.com/jo/g1/f/original/2016/02/09/portela_rodrigo_ gorosito_g1_img_9580.jpg.

GOROSITO, Rodrigo. Aladim da Mocidade voa na avenida. G1, Rio de Janeiro, 28 fev. 2017. 1 fotografia. Disponível em: https://s2.glbimg.com/WmBN_ NE2EaksqSJDt4A67ZwWj4g=/0x0:1900×1267/1008x0/smart/filters:strip_icc()/i. s3.glbimg.com/v1/AUTH_59edd422c0c84a879bd37670ae4f538a/internal_photos/ bs/2017/g/1/85e7zsSHGYV3ZQTBfTzg/padre-miguel-rodrigo-gorosito-g1goro3660.jpg.

LOPES, Bárbara. Paulo Barros, no barracão da Viradouro. Extra, Rio de Janeiro, 4 maio 2018. 1 fotografia. Disponível em: https://extra.globo.com/incoming/22651523ecb-23b/w448h673-PROP/xinfochpdpict000076530823.jpg.pagespeed. ic.XKWIZ8NOAk.jpg.

LUZ, Ana Luiza da. A teatralidade para além dos palcos na avenida do carnaval. Textos escolhidos de cultura e artes populares, Rio de Janeiro: UERJ - Instituto de Artes, v. 10, n. 2, p. 127-150, 2013. 
MARIÁTEGUI, José-Carlos. Sobre o futuro da arte e da ciência através da inventividade humana. Tradução Flávia Gisele Saretta. In: DOMINGUES, Diana (org.). Arte e vida no século XXI: tecnologia, ciência e criatividade. São Paulo: Ed. Unesp, 2003.

MELLO, Káthia; LESSA, Karen. "Emoção indescritível", diz destaque do abre-alas da Portela. Globo.com, 9 fev. 2016. Disponível em: http://g1.globo.com/rio-de-janeiro/ carnaval/2016/noticia/2016/02/emocao-indescritivel-diz-destaque-do-abre-alasda-portela.html. Acesso em: 17 set. 2018.

MENDONÇA, Alba Valéria; BOECKEL, Cristina; BARREIRA, Gabriel. Saia de portabandeira da Vila "pega fogo" com efeito de 20 mil lâmpadas de LED. Globo.com, 12 fev. 2018. Disponível em: https://g1.globo.com/rj/rio-de-janeiro/carnaval/2018/ noticia/paulo-barros-usa-dois-quilometros-de-led-no-abre-alas-da-vila-isabel. ghtml. Acesso em: 17 set. 2018.

SIBILIA, Paula. O homem pós-orgânico: a alquimia dos corpos e das almas à luz das tecnologias digitais. 2. ed. Rio de Janeiro: Contraponto, 2015.

TECNOLOGIA LED é sucesso no Carnaval. FOXLUX, [s. d.]. Disponível em: https:// www.foxlux.com.br/blog/dicas/tecnologia-led-e-sucesso-no-carnaval/. Acesso em: 17 set. 2018.

TEIXEIRA, Marco Antônio. Carro alegórico da Pirâmide humana representando o DNA. O Globo, Rio de Janeiro, 22 abr. 2004. 1 fotografia. Disponível em: https:// oglobo.globo.com/rio/carnaval/2014/os-carnavais-de-paulo-barros-no-grupoespecial-11296475.

TESI, Romulo. Mundo de Gulliver carnavalesco: conheça as escolas de samba de maquete. Setor 1, 2017. Disponível em: https://setor1.band.uol.com.br/. Acesso em: 22 set. 2018.

UESM - UNIÃO DAS ESCOLAS DE SAMBA DE MAQUETE. Grêmio Recreativo Escola de Samba de Maquete Arco Íris. 1 figura. Disponível em: http://www.uesm.com.br/ wp-content/uploads/2018/05/arcoiris.jpg.

UESM - UNIÃO DAS ESCOLAS DE SAMBA DE MAQUETE. Grêmio Recreativo Escola de Samba de Maquete Unidos do Tijucano. 1 figura. Disponível em: http://www. uesm.com.br/wp-content/uploads/2018/05/tijucano.jpg.

UESM - UNIÃO DAS ESCOLAS DE SAMBA DE MAQUETE. Regulamento: participação nos desfiles. Disponível em: http://www.uesm.com.br/regulamento/. Acesso em: 22 set. 2018. 